\title{
Active but nonculturable cells of Salmonella enterica serovar Typhimurium do not infect or colonize mice
}

\author{
Rebecca J. Smith, ${ }^{1}$ Angela T. Newton, ${ }^{2}$ Colin R. Harwood ${ }^{2}$ \\ and Michael R. Barer ${ }^{1}$
}

\begin{abstract}
Author for correspondence: Rebecca J. Smith. Tel: +44 116252 2955. Fax: +44 1162525030 e-mail: rjs29@le.ac.uk
\end{abstract}

\footnotetext{
1 Department of Microbiology and Immunology, Medical Sciences Building, PO Box 138, University Road, Leicester LE1 9HN, UK

2 Department of Microbiology and Immunology, University of Newcastle, Newcastle upon Tyne NE2 4HH, UK
}

\begin{abstract}
The possibility that nonculturable cells of a normally culturable bacterial pathogen may constitute a source or reservoir for infective disease was investigated. In multiple experiments and with careful attention to the statistical limitations of the assays used, Salmonella enterica serovar Typhimurium cells rendered nonculturable by carbon and nitrogen stress in the presence of chloramphenicol were administered orally and intraperitoneally to over 300 female BALB/c mice. Neither infection nor colonization was detected in these studies, even when active but nonculturable (ABNC) cells, as defined by the Kogure cell elongation assay, were present in the inoculum. Doses of ABNC cells exceeding the oral and intraperitoneal $L_{50}$ values by 3.5 and 2 orders of magnitude, respectively, were administered. It was concluded that ABNC cells of the salmonella strains used could not be considered potentially infective and that their detection in samples from material being evaluated as a potential source or reservoir of infection by the Kogure test does not specifically represent an infective hazard.
\end{abstract}

Keywords: viable but nonculturable, viability testing, infectivity

\section{INTRODUCTION}

The recognition of sources and reservoirs of bacterial pathogens is a central issue in the control of infectious diseases. Until the 1980s this was achieved by isolation of the pathogen concerned from appropriate sample material. Two developments, the establishment of molecular detection methodologies and the proposal that some bacteria may enter a 'viable but nonculturable' (VBNC) state, require us to re-evaluate this approach. Molecular detection methods can reveal the presence of nucleotide sequences or antigens in diverse sample materials. Their application has revealed a distribution of enteric pathogens that was not detected by culture methods within an epidemiologically defined population (Gaudio et al., 1997). However, without special modifications (e.g. Holmstrom et al., 1999; Sheridan et al., 1998), such methods cannot reveal the

Abbreviations: $A B N C$, active but nonculturable; $C C N$, chloramphenicoltreated carbon/nitrogen-stressed; MCCN, minimally stressed CCN; i.p., intraperitoneal(ly); MPN, most probable number; TCC, total cell count; VBNC, viable but nonculturable. physiological state of the detected bacteria and, as far as we are aware, no studies have defined molecular signals that can indicate their infective potential.

The VBNC hypothesis proposes that some bacteria that are normally readily culturable may enter a state in which they cannot be recovered by standard culture methods and may, nonetheless, retain 'viability' (Barer et al., 1993; Roszak \& Colwell, 1987; Xu et al., 1982). This 'viability' has been recognized by various cellular tests of activity and integrity and by a limited number of instances in which a return to culturability has been demonstrated in vitro or after animal passage (Cappelier et al., 1999a, b; Kell et al., 1998; Oliver \& Bockian, 1995; Bovill \& Mackey, 1997; Whitesides \& Oliver, 1997; Ravel et al., 1995; Stern et al., 1994; Nilsson et al., 1991; Saha et al., 1991). Many major pathogens, including Vibrio cholerae (Colwell, 1996; Xu et al., 1982), Campylobacter jejuni (Bovill \& Mackey, 1997; Rollins \& Colwell, 1986), Helicobacter pylori (Gribbon \& Barer, 1995; Shahamat et al., 1993) and Salmonella enterica (Desmonts et al., 1990; Roszak et al., 1984), are claimed to be able to enter a VBNC state. While the terminology used, the underlying processes involved and 
some of the reported data remain controversial (Barer $e t$ al., 1998; Bloomfield et al., 1998; Bogosian, 1998; Kell et al., 1998; Oliver, 1999), the possibility that temporarily nonculturable bacteria may be a source or reservoir of infection clearly exists.

Transmission and establishment of a bacterial pathogen from a source to a potential host requires that the pathogen be in an appropriate physiological state, the definition of which remains incomplete. The proposal that some bacteria may enter a physiological VBNC state raises the possibility that pathogens that cannot be detected by conventional culture in potential sources or reservoirs of infection may, nonetheless, be able to initiate infection.

Examples in which culture methods failed to detect the pathogen in likely sources or reservoirs of infection which were positive by molecular biological or immunological methods include cholera (Brayton et al., 1987), campylobacteriosis (Palmer et al., 1983; Pearson et al., 1993) and shigellosis (Gaudio et al., 1997). Although some methods, such as the detection of RNA by RTPCR (e.g. Holmstrom et al., 1999; Sheridan et al., 1998), provide a step towards defining the relationship between molecular detection signals and infective potential, the application of these approaches has been very limited.

In this study we have extended a well-standardized and quantitative animal infection system (Hormaeche, 1979) to address directly the issue of whether nonculturable cells of culturable bacterial pathogens have infective potential. Our primary concerns have been to prepare cells that were rendered nonculturable by physiologically defined stresses, that the bacterial cellular phenotypes present in animal inocula should be specified in terms of active and inactive components, and that the precision of the infectivity assays should be statistically defined. Colony-forming ability and broth-dilution recovery (most probable number counts) were used to assess culturability and cellular activity was determined by a modified Kogure cell elongation assay (Kogure et al., 1979). The latter demonstrates the capacity of nonculturable cells to elongate in response to low nutrient levels and exposure to a quinolone antimicrobial. We used the same nutrient conditions for the broth recovery and the activity test. Thus, where activity was detected we could be confident that a proportion of the cells inoculated into the broth-dilution test had the capacity for limited growth in the same medium.

Several reports concerning the infectivity of nonculturable bacteria have used animal systems for which there is limited background experience. Therefore we chose Salmonella enterica serovar Typhimurium ( $S$. typhimurium) and the female BALB/c mouse model for infection studies because we wanted to present our data against the existing extensive background of studies that have used this quantitative infectivity assay. Both oral and intraperitoneal administration were used since both have been reported to support resuscitation of nonculturable bacteria (Jones et al., 1991; Oliver \& Bockian,
1995). Moreover, the C5 strain of S. typhimurium is known to have an intraperitoneal $\mathrm{LD}_{50}$ in the BALB/c system of $1-10$ organisms and therefore provides a very sensitive detection system.

The primary aims of this study were: (1) to determine the infective potential of nonculturable cells in the system described and (2) to determine whether active but nonculturable (ABNC) cell counts provide an indication of such retained infectivity. The latter is an important practical issue since the detection of activity remains the principal means by which putative viability and, by implication, infectivity has been determined previously. Our experiments were also designed to determine the value of the Kogure activity assay used here as a means of assessing the hazards posed by detected nonculturable cells. Finally, the use of terms such as viability and death in this field remains controversial (Barer et al., 1998; Bloomfield et al., 1998; Bogosian, 1998; Kell et al., 1998; Oliver, 1999). Where possible we avoid the use of such interpretative terms herein and adhere to a published set of definitions for all potentially ambiguous terms (Barer \& Harwood, 1999).

\section{METHODS}

Bacterial strains and media. S. typhimurium C5 (Hormaeche, 1979) has been extensively investigated in virulence studies (Hormaeche et al., 1995). S. typhimurium $\mathrm{C} 5 \mathrm{Nx}^{\mathrm{r}}$, a spontaneous nalidixic-acid-resistant derivative of C5 (Maskell et al., 1987a), was used in the majority of studies. Both strains were cultured in Luria-Bertani broth (LB, $10 \mathrm{~g}$ tryptone $\mathrm{l}^{-1}$, $10 \mathrm{~g}$ sodium chloride $\mathrm{l}^{-1}, 5 \mathrm{~g}$ yeast extract $\left.\mathrm{l}^{-1}\right)$ and maintained on LB agar. LB broth was diluted $1 / 10$ with double-distilled $\mathrm{H}_{2} \mathrm{O}$ to provide $10 \%(\mathrm{v} / \mathrm{v})$ LB. Sodium mannitol selenite (SMS) broth (4 g sodium biselenite $\mathrm{l}^{-1}, 19 \mathrm{~g}$ mannitol selenite broth base $\mathrm{l}^{-1}$; Oxoid) was used as an enrichment medium for salmonella. For isolation and differentiation of Salmonella spp., xylene lysine deoxycholate (XLD) agar (Oxoid) was used. In experiments using $S$. typhimurium $\mathrm{C} 5 \mathrm{Nx}^{\mathrm{r}}$, both SMS broth and XLD agar contained nalidixic acid $\left(50 \mu \mathrm{g} \mathrm{ml}^{-1}\right)$.

Generation of chloramphenicol, carbon and nitrogen (CCN)stressed and minimally CCN (MCCN)-stressed populations of S. typhimurium. Nonculturabilty was induced by subjecting the test strains to carbon/nitrogen stress in the presence of chloramphenicol (CCN stress) as described previously (Nwoguh et al., 1995). Briefly, test strains were grown overnight in LB broth at $37^{\circ} \mathrm{C}$ on a rotary shaker (200 r.p.m.), diluted into $100 \mathrm{ml} \mathrm{LB}$ broth to an $\mathrm{OD}_{600}$ of 0.05 and grown to an $\mathrm{OD}_{600}$ of $0 \cdot 2$. This dilution process was repeated twice and the final growth period extended to $\mathrm{OD}_{600} 0 \cdot 3$. These exponential-phase cells were harvested, washed three times with phosphate-buffered saline $\mathrm{pH} 7 \cdot 3$ (PBS) and resuspended in PBS containing chloramphenicol $\left(100 \mu \mathrm{g} \mathrm{ml}^{-1}\right)$, to a final density of approximately $10^{8}$ cells $\mathrm{ml}^{-1}$. The resultant preparations were divided into $50 \mathrm{ml}$ volumes and were maintained statically in $100 \mathrm{ml}$ Duran bottles at $37^{\circ} \mathrm{C}$. The initiation of CCN stress was defined as $T_{0}$ and subsequent daily intervals as $T_{1}, T_{2}, T_{3}$, etc. Control populations for determining the effects of CCN stress were made by resuspending exponentialphase cells in chloramphenicol-free PBS.

Minimally stressed CCN (MCCN) cultures were defined as cultures with dissociation between colony-forming and total 
cell counts of 5-7 $\log _{10}$ units. This was the minimum level at which inocula could be prepared with confidence that no colony-forming cells were present. The aim was to produce inocula in which some cells that had only just become nonculturable were present.

Colony-forming unit (c.f.u.) counts. Samples were decimally diluted in PBS and $20 \mu \mathrm{l}$ dropped in six replicates on pre-dried LB agar plates. When counts fell below the detection limit of 50 cells $\mathrm{ml}^{-1}, 200 \mu \mathrm{l}$ samples were spread onto five plates to reduce the detection limit to 1 c.f.u. $\mathrm{ml}^{-1}$.

Total cell counts (TCCS). Total cell counts were determined by microscopic enumeration in a Thoma counting chamber (Weber Scientific International). Samples were diluted and fixed with $4 \%(\mathrm{v} / \mathrm{v})$ formaldehyde buffered to $\mathrm{pH} 7 \cdot 2$ with solid $\mathrm{K}_{2} \mathrm{HPO}_{4}$ (Koch, 1994); samples were diluted further with $0 \cdot 1 \mathrm{M} \mathrm{HCl}$ before filling the counting chamber. Replicate samples were counted using phase-contrast microscopy. All 256 squares of the counting chamber were counted.

Most probable number (MPN) 5-tube method. Samples were decimally diluted down to $10^{-10}$ in $1.8 \mathrm{ml}$ volumes of $10 \%$ $(\mathrm{v} / \mathrm{v}) \mathrm{LB}$ broth; five replicates of the dilution series were used. The bijou bottles were held statically at $37^{\circ} \mathrm{C}$ and scored for turbidity after $24 \mathrm{~h}$; further changes in turbidity were recorded up to 2 weeks. MPN tables (Department of Health and Social Security, 1969) were then used to derive the MPN of organisms in the original samples.

Kogure elongation test. ABNC cells were identified by a modified Kogure elongation test (Barcina et al., 1995; Kogure et al., 1979). Cells were incubated overnight at $37^{\circ} \mathrm{C}$ in $10 \%$ $(\mathrm{w} / \mathrm{v})$ LB containing $0.5 \mu \mathrm{g}$ ofloxacin $\mathrm{ml}^{-1}$. Following incubation, cells were immobilized onto aminopropylsilanecoated coverslips as previously described (Barer, 1991). The resulting monolayer was fixed for $30 \mathrm{~s}$ with $4 \%(\mathrm{v} / \mathrm{v})$ paraformaldehyde and stained with $0 \cdot 1 \% \quad(\mathrm{w} / \mathrm{v})$ acridine orange. The distribution of cell lengths was determined for treated samples by analysis of digitized phase-contrast images as previously described (Whiteley et al., 1996, 1998) and compared to the mean cell length of the corresponding control population that had not been exposed to ofloxacin. Cells were scored positive for activity if their cell lengths were twice the mean cell length of the control population (Bogosian et al., 1998). In the results reported here this represented 3-4 standard deviations from the control mean; thus less than $0.1 \%$ of the control population would be expected to be scored positive by this criterion. It should be noted that Kogure determinations were not generally done on samples containing culturable cells (e.g. MCCN cells) because elongation was so extensive in some cells that accurate counts could not be achieved and because cell replication took place in control (ofloxacin-free) preparations. Where assays were done on such samples, 10-fold dilutions were performed prior to incubation and counts determined on the first dilution at which filamentous cells did not obscure the result (see Fig. 1).

Animal studies. Inocula for baseline $\mathrm{LD}_{50}$ studies and controls used subsequently to confirm the infective potential of culturable cells were prepared with cells harvested in the exponential phase and maintained in PBS at $37^{\circ} \mathrm{C}$ for $18-24 \mathrm{~h}$. In initial studies with the $\mathrm{C} 5$ strain we observed that the $\mathrm{LD}_{50}$ values of $24 \mathrm{~h}$ stationary-phase cells were not distinguishable from those obtained with the $24 \mathrm{~h} \mathrm{PBS}$-maintained cells. The doses were estimated on the basis of TCCs. Inocula of CCNstressed cells were prepared on the basis of c.f.u. counts relating to samples taken on the previous day. The cells were

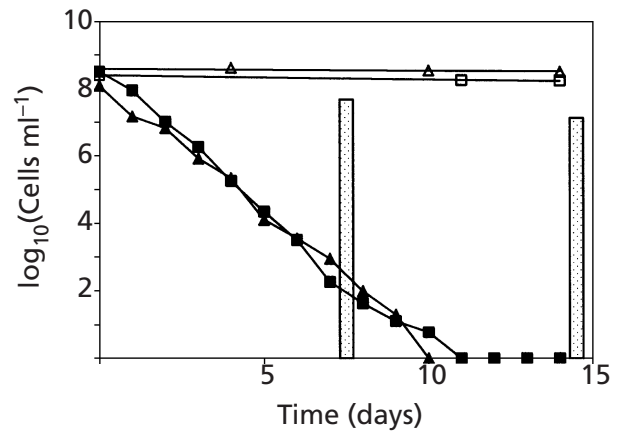

Fig. 1. Response to $C C N$ stress of $C 5$ and $C 5 N x^{r} . \triangle, C 5 T C C$; $\boldsymbol{\Delta}, \mathrm{C} 5$ c.f.u.; $\square, \mathrm{C} 5 \mathrm{Nx}^{\mathrm{r}} \mathrm{TCC} ; \boldsymbol{\square}, \mathrm{C} 5 \mathrm{Nx}^{\mathrm{r}}$ c.f.u. Kogure elongation counts for $\mathrm{C} 5 \mathrm{Nx}^{\mathrm{r}}$ are represented by the vertical bars.

harvested at $15000 \mathrm{~g}$ for $10 \mathrm{~min}$ at $37^{\circ} \mathrm{C}$, washed with PBS to remove residual traces of chloramphenicol, and resuspended in PBS. TCCs were determined and cell concentrations adjusted to the required dose; further decimal dilutions were performed in PBS. C.f.u. and MPN counts were performed on the inocula.

For experiments determining the infectivity of $\mathrm{ABNC}$, a nonculturable population was required. When CCN cells were nonculturable ( $<1$ c.f.u. $\mathrm{ml}^{-1}$ for 5 days), cells were harvested, washed with PBS and resuspended in $10 \%(\mathrm{w} / \mathrm{v})$ LB or PBS. Total cell counts were determined, and the cell concentration adjusted to the required dose. The inoculum was incubated statically at $37^{\circ} \mathrm{C}$ for $24 \mathrm{~h}$ prior to further decimal dilutions with $10 \%(\mathrm{w} / \mathrm{v})$ LB broth or PBS. C.f.u. counts, MPN counts and Kogure elongation test were performed to characterize the inocula.

Female inbred BALB/c mice (Harlan UK), aged 8-10 weeks and with a mean weight of $25 \mathrm{~g}$, were used. Groups of five mice were dosed either orally or intraperitoneally (i.p.) with 10 -fold serial dilutions of the test organism. Control mice were inoculated with either PBS or $10 \%$ (w/v) LB depending on the experiment. Mice were housed five per cage, and water and food were provided throughout the duration of the experiment. For oral challenge, mice were lightly anaesthetized with fluorothane and $0.2 \mathrm{ml}$ of inoculum was administered intragastrically via a gavage needle. Four days after oral challenge the bowel tissue and cage litter were examined for the test organism by SMS enrichment and direct culture. Bowel tissue was placed in SMS broth and homogenized (Silverson Machines) and cage litter was resuspended at $10 \%(\mathrm{w} / \mathrm{v})$ in SMS broth. Broths were incubated statically at $37^{\circ} \mathrm{C}$; samples were removed after 24 and $48 \mathrm{~h}$, plated onto XLD agar plates and incubated at $37^{\circ} \mathrm{C}$ for $24 \mathrm{~h}$. Mice dosed i.p. $(0 \cdot 2 \mathrm{ml}$ inoculum) were left for 28 days or until signs of infection developed. Livers and spleens were removed from fatally infected mice and were homogenized separately in $10 \mathrm{ml}$ distilled water in a Colworth stomacher (Hormaeche, 1979). The resultant homogenates were decimally diluted in PBS and the numbers of culturable cells determined by pour plating in LB agar (Maskell et al., 1987b). Putative Salmonella colonies were screened on XLD agar plates; subsequent $\mathrm{H}_{2} \mathrm{~S}$-reducing colonies were tested for positive agglutination reactions with Salmonella agglutinating sera (Murex Diagnostics).

All the animal experiments were performed under licence 
from the Home Office (UK). Animals were killed by cervical dislocation.

Mixed-culture experiment. S. typhimurium C5 and C5Nx ${ }^{\mathrm{r}}$ were used in this experiment. MCCN C5Nx ${ }^{r}$ cells were generated as described previously and resuspended in $10 \%$ (w/v) LB broth. Inocula were characterized by performing MPN counts and the modified Kogure test. S. typhimurium C5 was grown to exponential phase in LB broth. Mice were inoculated orally with $0.2 \mathrm{ml}$ volumes of the mixed culture sample $\left(50: 50, \mathrm{C} 5: \mathrm{C} 5 \mathrm{Nx}^{\mathrm{r}}\right)$ and mortality was recorded for up to 28 days. Liver and spleen samples were removed from fatally infected mice, processed and examined for the presence of the test organisms by culturing in SMS broth (with or without nalidixic acid at $50 \mu \mathrm{g} \mathrm{m}^{-1}$ ), and plating onto XLD plates (with or without nalidixic acid at $50 \mu \mathrm{g} \mathrm{ml}^{-1}$ ). Cage litter from all groups was examined (as described) every 3 days for the presence of the test organisms throughout the experiment. Bowel tissue was removed and examined from all mice that did not die within the 28 day period.

$\mathbf{L D}_{50}$ determination. The $\mathrm{LD}_{50}$ of chloramphenicol-treated and untreated $S$. typhimurium $\mathrm{C} 5 \mathrm{Nx}^{\mathrm{r}}$ cells was determined on groups of five female BALB/c mice. Briefly, the test organism was grown to exponential phase, washed and resuspended in PBS ( $\mathrm{pH} 7 \cdot 2)$, and chloramphenicol added $\left(100 \mu \mathrm{g} \mathrm{ml}^{-1}\right)$ as required. Following incubation for $24 \mathrm{~h}$ at $37^{\circ} \mathrm{C}$, inocula were prepared by washing and resuspending the cells in PBS. The mice were inoculated orally or i.p. with $0.2 \mathrm{ml}$ volumes of decimal dilutions of cells in PBS. Mortality was recorded up to 28 days, and the $\mathrm{LD}_{50}$ determined by the method of Williams (1986), an approach that enables estimation of confidence intervals by the asymptotic ratio test.

\section{RESULTS}

Initial animal experiments were performed with S. typhimurium strain C5. In later experiments a nalidixicacid-resistant derivative of this strain, $\mathrm{C} 5 \mathrm{Nx}^{\mathrm{r}}$, was used to facilitate selective isolation. Infective potential (ability to establish overt infection) was predominantly studied with i.p. inoculations; oral inoculations were generally used to investigate capacity for resuscitation of nonculturable cells.

\section{Responses to chloramphenicol, carbon and nitrogen (CCN) stress}

Populations of nonculturable cells were prepared using well-defined protocols that had previously been shown to produce active but nonculturable (ABNC) cells using cellular detection of inducible $\beta$-galactosidase activity as a means of determining cellular activity (Nwoguh et al., 1995). The responses of exponential-phase populations of strains $\mathrm{C} 5$ and $\mathrm{C} 5 \mathrm{Nx}^{\mathrm{r}}$ to $\mathrm{CCN}$ stress at $37^{\circ} \mathrm{C}$ were monitored by c.f.u. counts and total cell counts (TCCs). Fig. 1 shows a representative pattern of decline in a single microcosm of $\mathrm{C} 5 \mathrm{Nx}^{\mathrm{r}}$ and $\mathrm{C} 5$ over a period of 14 days. While the c.f.u. counts declined by $8 \log _{10}$ units over this period, there was no discernible change in TCC. When these strains were subjected to carbon and nitrogen stress in the absence of chloramphenicol, c.f.u. counts declined by $3 \log _{10}$ units over a period of 35 days, after which no further decrease was observed for up to 6 months (data not shown).

\section{$\mathrm{LD}_{50}$ determinations}

The numbers of culturable $\mathrm{C} 5 \mathrm{Nx}^{\mathrm{r}}$ cells required to cause $50 \%$ mortality $\left(\mathrm{LD}_{50}\right)$ in BALB/c mice orally and i.p. were determined as $4.92( \pm 0.75)$ and $1.14( \pm 0 \cdot 26) \log _{10}$ units, respectively; figures in parentheses denote limits for $95 \%$ likelihood based confidence intervals (see Methods). $\mathrm{LD}_{50}$ values for strain C5 fell well within these confidence limits ( 4.89 and $1 \cdot 18$, respectively). To determine whether chloramphenicol exposure affected virulence, $\mathrm{C} 5 \mathrm{Nx}^{\mathrm{r}}$ cells were treated with $100 \mu \mathrm{g}$ chloramphenicol ml $\mathrm{ml}^{-1}$ in PBS for $24 \mathrm{~h}$ prior to administration. The resultant $\mathrm{LD}_{50}$ values for oral and i.p. inoculations were determined as $4.16( \pm 1.05)$ and $1.20( \pm 0.20) \log _{10}$ units respectively, values that were effectively indistinguishable from those obtained with untreated cells.

\section{I.p. administration of nonculturable minimally $\mathrm{CCN}$ (MCCN)-stressed cells in BALB/c mice}

Initial experiments explored the infectivity of MCCNstressed S. typhimurium strain C5. BALB/c mice were challenged i.p. with samples containing approximately 200 stressed cells and for which the probability that a single culturable cell was present was $<0 \cdot 01$ (by c.f.u. and MPN). All inoculated mice survived for 28 days and did not develop signs of infection (data not shown). Spleens and livers were removed at 28 days but no culturable S. typhimurium cells were detected. In contrast, all mice inoculated with the same number of control, c.f.u.-forming cells that had been held in PBS at $37^{\circ} \mathrm{C}$ for $24 \mathrm{~h}$ died within $5-10$ days; the test organism was subsequently recovered from both their livers and their spleens.

The remaining infectivity experiments were performed using strain $\mathrm{C} 5 \mathrm{Nx}^{\mathrm{r}}$. Over a series of experiments, 75 female BALB/c mice were challenged i.p. with doses containing $10^{2}-10^{4} \mathrm{MCCN}$ stressed cells. The doses and outcome of one experiment are shown in Table 1 (the results of parallel oral inoculations are discussed below). Total cells inoculated exceeded the $\mathrm{LD}_{50}$ by $0 \cdot 8-3 \cdot 8 \log _{10}$ units and the presence of culturable cells was excluded by MPN counts. All mice inoculated with these doses survived for 28 days and did not develop signs of infection.

\section{I.p. administration of ABNC cells does not cause infections}

Colwell et al. (1996) incubated nonculturable cells of $V$. cholerae in a low-nutrient medium prior to preparing them for oral dosing in human volunteer studies. To assess the effect of comparable preparations in our studies, nonculturable CCN-stressed cells of $\mathrm{C} 5 \mathrm{Nx}^{\mathrm{r}}$ were resuspended in chloramphenicol-free PBS or $10 \%$ $(\mathrm{w} / \mathrm{v}) \mathrm{LB}$; the PBS suspensions were administered immediately while the $10 \%$ LB suspensions were maintained at $37^{\circ} \mathrm{C}$ for $24 \mathrm{~h}$ prior to administration and the number of elongation-positive (ABNC) cells determined on the day of inoculation. The infective potential of cell 
Table 1. I.p. and oral administration of MCCN-stressed nonculturable S. typhimurium $\mathrm{C} 5 \mathrm{Nx}^{\mathrm{r}}$ cells to $\mathrm{BALB} / \mathrm{c}$ mice

\begin{tabular}{|c|c|c|c|c|c|}
\hline \multirow[t]{2}{*}{ Route } & \multirow[t]{2}{*}{ Dilution } & \multicolumn{2}{|c|}{ Doses administered } & \multicolumn{2}{|c|}{ Outcome } \\
\hline & & TCC & c.f.u. & $\mathrm{MPN}+\mathrm{ve}^{*}$ & Mice + ve $\dagger$ \\
\hline \multirow[t]{4}{*}{ I.p. } & $0 \cdot 01$ & 50100 & 0 & 1 & 0 \\
\hline & $0 \cdot 001$ & 5010 & 0 & 0 & 0 \\
\hline & $0 \cdot 0001$ & 501 & 0 & 0 & 0 \\
\hline & $0 \cdot 00001$ & 50 & 0 & 0 & 0 \\
\hline \multirow[t]{4}{*}{ Oral } & 1 & 5010000 & 39 & 5 & 0 \\
\hline & $0 \cdot 1$ & 501000 & 4 & 5 & 0 \\
\hline & $0 \cdot 01$ & 50100 & 0 & 1 & 0 \\
\hline & $0 \cdot 001$ & 5010 & 0 & 0 & 0 \\
\hline
\end{tabular}

*Number of tubes positive for growth at this dilution in 5-tube MPN test.

† Number of mice in which infections were detected (i.p. studies only) and number of mice from which culturable S. typhmurium $\mathrm{C} 5 \mathrm{Nx}^{\mathrm{r}}$ cells were recovered (oral and i.p. studies). Five mice were inoculated at each dilution to make the studies directly comparable with the MPN test.

Table 2. I.p. and oral administration of S. typhimurium $\mathrm{C} 5 \mathrm{Nx}^{\mathrm{r}}$ populations with defined ABNC cell content

\begin{tabular}{|c|c|c|c|c|c|c|c|c|c|c|c|}
\hline \multirow[t]{3}{*}{ Route } & \multirow[t]{3}{*}{ Dilution } & \multicolumn{6}{|c|}{ Doses administered } & \multicolumn{4}{|c|}{ Outcomes } \\
\hline & & \multicolumn{2}{|c|}{ TCC } & \multicolumn{2}{|c|}{ ABNC } & \multicolumn{2}{|c|}{ c.f.u. } & \multicolumn{2}{|c|}{$\mathrm{MPN}+\mathrm{ve}^{*}$} & \multicolumn{2}{|c|}{ Mice + ve $†$} \\
\hline & & PBS & $\begin{array}{c}10 \% \\
\text { LB }\end{array}$ & PBS & $\begin{array}{c}10 \% \\
\text { LB }\end{array}$ & PBS & $\begin{array}{c}10 \% \\
\text { LB }\end{array}$ & PBS & $\begin{array}{c}10 \% \\
\text { LB }\end{array}$ & PBS & $\begin{array}{c}10 \% \\
\text { LB }\end{array}$ \\
\hline I.p.‡ & NA & NA & NA & $\mathrm{NA}$ & NA & $3 \cdot 3$ & NA & NA & NA & 3 & NA \\
\hline I.p. & 1 & 4000 & 95500 & $48 \mathbb{S}$ & $759 \$$ & 0 & 0 & 0 & 0 & 0 & 0 \\
\hline I.p. & $0 \cdot 1$ & 400 & 9550 & 5 & $76 \mathbb{S}$ & 0 & 0 & 0 & 0 & 0 & 0 \\
\hline I.p. & $0 \cdot 01$ & 40 & 955 & 0 & 8 & 0 & 0 & 0 & 0 & 0 & 0 \\
\hline I.p. & $0 \cdot 001$ & 4 & 96 & 0 & 0 & 0 & 0 & 0 & 0 & 0 & 0 \\
\hline Oralł & NA & NA & NA & NA & NA & 330000 & NA & NA & NA & 5 & NA \\
\hline Oral & 1 & 117500000 & 9540000000 & $1445440 \$$ & $75857757 \$$ & 0 & 0 & 0 & 0 & 0 & 0 \\
\hline Oral & $0 \cdot 1$ & 11750000 & 954000000 & $144544 \mathbb{S}$ & $7585776 \mathbb{S}$ & 0 & 0 & 0 & 0 & 0 & 0 \\
\hline Oral & $0 \cdot 01$ & 1175000 & 95400000 & 14454 & $758578 \mathbb{S}$ & 0 & 0 & 0 & 0 & 0 & 0 \\
\hline Oral & $0 \cdot 001$ & 117500 & 9540000 & 1445 & 75858 & 0 & 0 & 0 & 0 & 0 & 0 \\
\hline
\end{tabular}

NA, Not applicable.

* Number of tubes positive for growth at this dilution in 5-tube MPN test.

† Number of mice in which infections were detected (i.p. studies only) and number of mice from which culturable S. typhmurium C5Nx ${ }^{\mathrm{r}}$ cells were recovered (i.p. and oral studies). Five mice were inoculated at each dilution to make the studies directly comparable with the MPN test.

$\ddagger$ Positive control inoculum.

\Dose above $\mathrm{LD}_{50}$ for c.f.u. $\left(\mathrm{LD}_{50}\right.$ : i.p. 14 c.f.u., oral 83000 c.f.u.).

populations containing these ABNC cells was investigated and the results are shown in Table 2 (upper half). None of the mice, including those challenged with doses of ABNC cells that exceeded the $\mathrm{LD}_{50}$ by $0 \cdot 81-2 \cdot 01 \log _{10}$ units, developed signs of infection over the 28 day observation period. MPN counts confirmed the absence of culturable cells in the inocula. In concurrent control studies, five mice were challenged i.p. with a dose estimated at $3 \cdot 3$ c.f.u. of cells maintained in PBS for 24 h. Three of these mice died over the 28 day observation period and culturable $\mathrm{C} 5 \mathrm{Nx}^{\mathrm{r}}$ cells were recovered from their livers and spleens. 
Table 3. Oral administration of a mixed culture of $S$. typhimurium $C 5$ (culturable) and $\mathrm{C} 5 \mathrm{Nx}^{\mathrm{r}}$ (MCCN-stressed) inoculum to BALB/c mice

\begin{tabular}{|c|c|c|c|c|c|c|}
\hline \multirow[t]{3}{*}{ Inoculum } & \multicolumn{4}{|c|}{ Doses administered } & \multicolumn{2}{|c|}{ Outcome* } \\
\hline & \multirow{2}{*}{$\begin{array}{c}\text { C5 } \\
\text { c.f.u. }\end{array}$} & \multicolumn{3}{|c|}{$\mathrm{C} 5 \mathrm{Nx}^{\mathrm{r}}$} & \multirow[t]{2}{*}{ C5 } & \multirow{2}{*}{$\mathrm{C} 5 \mathrm{Nx}^{\mathrm{r}}$} \\
\hline & & TCC & $\mathrm{ABNC}$ & c.f.u. & & \\
\hline \multirow[t]{4}{*}{$\mathrm{C} 5+\mathrm{C} 5 \mathrm{Nx}^{\mathrm{r}}$} & $10^{6}$ & $10^{7}$ & $4.6 \times 10^{5}$ & 4 & 5 & 0 \\
\hline & $10^{5}$ & $10^{7}$ & $4 \cdot 6 \times 10^{5}$ & 4 & 5 & 0 \\
\hline & $10^{4}$ & $10^{7}$ & $4.6 \times 10^{5}$ & 4 & 3 & 0 \\
\hline & $10^{3}$ & $10^{7}$ & $4.6 \times 10^{5}$ & 4 & 1 & 0 \\
\hline \multirow{4}{*}{$\mathrm{C} 5+\mathrm{C} 5 \mathrm{Nx}^{\mathrm{r}}$} & $10^{6}$ & $10^{4}$ & $4.6 \times 10^{2}$ & 0 & 5 & 0 \\
\hline & $10^{5}$ & $10^{4}$ & $4.6 \times 10^{2}$ & 0 & 5 & 0 \\
\hline & $10^{4}$ & $10^{4}$ & $4 \cdot 6 \times 10^{2}$ & 0 & 5 & 0 \\
\hline & $10^{3}$ & $10^{4}$ & $4.6 \times 10^{2}$ & 0 & 2 & 0 \\
\hline \multirow[t]{4}{*}{$\mathrm{C} 5$} & $10^{6}$ & - & - & - & 5 & 0 \\
\hline & $10^{5}$ & - & - & - & 5 & 0 \\
\hline & $10^{4}$ & - & - & - & 3 & 0 \\
\hline & $10^{3}$ & - & - & - & 2 & 0 \\
\hline
\end{tabular}

*Score indicates the number of mice from which S. typhimurium C5 and/or C5 $\mathrm{Nx}^{\mathrm{r}}$ cells were recovered. Tissue and/or litter samples were plated (after selenite enrichment with or without nalidixic acid) onto XLD plates with or without nalidixic acid $\left(50 \mu \mathrm{g} \mathrm{ml}^{-1}\right)$.

I.p. inoculation clearly provides a more sensitive assay for retained infectivity than oral inoculation. Nonetheless, the ability to establish overt infection by oral inoculation of CCN-stressed nonculturable cells was investigated extensively in the initial phase of the study; the maximum dose administered orally was 8.9 $\log _{10}$ units. However, as no such infections were seen over the 28 day observation period and no bacteria were recovered by culture of litter or organs in any of these experiments (data not shown), it was decided to focus oral inoculation studies on the question of whether nonculturable cells could be resuscitated via gut passage.

\section{Attempted resuscitation of nonculturable MCCN- stressed cells via oral inoculations in mice}

In multiple experiments, cells were prepared for inoculation into mice when c.f.u. counts of MCCNstressed populations of strains $\mathrm{C} 5$ and $\mathrm{C} 5 \mathrm{Nx}^{\mathrm{r}}$ showed dissociations of 5-7 $\log _{10}$ units against the TCC. In initial experiments strain C5 was used as the test organism and, following selenite enrichment of samples, $\mathrm{H}_{2} \mathrm{~S}$-reducing colonies resembling Salmonella spp. were observed on several occasions. However, the organisms proved difficult to isolate and we were only able to obtain a pure culture that gave the appropriate biochemical and agglutination reactions for S. typhimurium on one occasion. Most $\mathrm{H}_{2} \mathrm{~S}$-positive colonies isolated from the samples proved to be Proteus spp. Subsequently we used the nalidixic-acid-resistant strain, $\mathrm{C} 5 \mathrm{Nx}^{\mathrm{r}}$, which could be selectively isolated from the background flora.
In three experiments done in parallel with those for the infectivity studies described above (Table 1), doses containing $10^{3}-10^{7}$ MCCN-stressed C5 $\mathrm{Nx}^{\mathrm{r}}$ cells were administered orally to $75 \mathrm{female} \mathrm{BALB} / \mathrm{c}$ mice over three experiments. $\mathrm{C} 5 \mathrm{Nx}^{\mathrm{r}}$ cells were not recovered from any of the mice at any of the doses even though the highest doses were 1.4-2.4 $\log _{10}$ units above the $\mathrm{LD}_{50}$ and some of the oral doses contained culturable cells (Table 1).

\section{Attempted resuscitation via oral inoculation using nonculturable inocula containing defined numbers of ABNC cells}

We next investigated the possibility that ABNC cells in the inoculum might be capable of resuscitation. Inocula were prepared as described above in relation to Table 2. The doses were calculated with respect to cell elongation determinations to provide inocula of ABNC cells that exceeded the oral $\mathrm{LD}_{50}$ determined previously. Four days following oral challenge, the mice were killed, and bowel tissue and cage litter were examined for the presence of the test organism. Groups of five BALB/c mice were challenged orally; doses and outcomes are indicated in Table 2 (lower half). No cell resuscitation/ recovery events were observed in any mice and no growth was observed in any of the MPN tubes relating to the inocula used. In a concurrent control experiment in which five mice were challenged orally with $3.3 \times$ $10^{5}$ c.f.u. of $\mathrm{C} 5 \mathrm{Nx}^{\mathrm{r}}$ cells that had been maintained in PBS for $24 \mathrm{~h}$, colonies were recovered from the bowel tissue of all five mice. 


\section{Mixed-culture experiment}

It has been reported that culturable cells expressing a 'resuscitation factor' may induce a return to culturability in a temporarily nonculturable population (Kaprelyants \& Kell, 1994; Votyakova et al., 1994) and an in vitro mixed culture test has been developed in an attempt to exploit this phenomenon (Bogosian et al., 1998). The possibility that culturable cells could facilitate resuscitation of nonculturable cells in vivo was explored by preparing inocula containing mixtures of easily distinguishable culturable and nonculturable cells that were administered orally to groups of five BALB/c mice. Mixed preparations of culturable, chloramphenicoltreated S. typhimurium C5 cells and MCCN-stressed $\mathrm{C} 5 \mathrm{Nx}^{\mathrm{r}}$ cells were prepared and the subsequent recovery of the latter nonculturable cells tested by plating on XLD plates containing nalidixic acid. Two dose levels of C5 $\mathrm{Nx}^{\mathrm{r}}$ (TCC of $10^{7}$ or $10^{4}$ cells) were tested and the ABNC content determined. The dose range of C5 cells $\left(10^{3}-10^{6}\right)$ was prepared such that it straddled the $\mathrm{LD}_{50}$ for the test organism. A control group inoculated with culturable C5 cells only was also included to assess whether addition of nonculturable C5Nx ${ }^{\mathrm{r}}$ cells affected the outcome. Spleen and liver tissue removed from fatally infected mice, and cage litter from all groups, were examined for the presence of 'resuscitated' nonculturable cells of C $5 \mathrm{Nx}^{\mathrm{r}}$ over 28 days. Doses and outcomes are shown in Table 3. S. typhimurium $\mathrm{C} 5 \mathrm{Nx}^{\mathrm{r}}$ was not recovered from any sample and the infectivity of C5 was the same with and without the addition of MCCNstressed $\mathrm{C} 5 \mathrm{Nx}^{\mathrm{r}}$.

\section{DISCUSSION}

We have used closely defined conditions and test procedures that are both widely used and wellstandardized to study the hypothesis that apparently nonculturable cells of normally culturable bacterial pathogens may have the capacity to resuscitate (i.e. become culturable) or initiate infections in vivo. Although this is not a hypothesis that can be falsified in the sense defined by Karl Popper (Popper, 1972), using nonculturable cells prepared under conditions tested here we have found no evidence to support this hypothesis.

Exponential-phase cells of S. typhimurium were rendered nonculturable by maintenance in phosphatebuffered, carbon- and nitrogen-free medium (PBS) in the presence of chloramphenicol (CCN stress). This approach yields substantial populations of intact bacterial cells that retain the capacity to respond to a specific external stimulus with de novo transcription and translation to form functional polypeptides (Nwoguh et al., 1995). The physiological basis for the cell changes observed in the modified Kogure method used here is not defined (Barer et al., 1993; Kogure et al., 1979), although it is likely that transcription, translation and considerable metabolic activity are required (Barer \& Harwood, 1999; Kell et al., 1998). In our studies and in other laboratories, it has been recognized that the capacity to respond in the Kogure test is lost relatively early after cells are rendered nonculturable compared to other indicators of cell activity or integrity (Joux et al., 1997; Lisle et al., 1999). As far as we are aware, the statistical issues relating to scoring cells positive in this assay have not previously been discussed and we have taken particular care to ensure that our ABNC counts could not be attributable to random variation between test and control populations.

It was noted that, in spite of using the same medium for the ABNC and MPN counts, the latter gave results closely corresponding to the c.f.u. counts $\left( \pm 0 \cdot 2 \log _{10}\right.$ units where c.f.u. counts were above the limit of detection) in all the assays relating to the experiments reported here (data not shown). The MPN recovery method in unshaken nutrient-poor medium should avoid the problems of metabolic self-destruction that have been suggested as a basis for some nonculturable phenomena (Barer \& Harwood, 1999). Apparently cells capable of elongation in the Kogure test medium used here are not necessarily able to replicate sufficiently to produce visible turbidity in the same medium.

In light of these background considerations, we consider that the inocula we used in our animal experiments comprised unambiguously nonculturable cells and that they contained a subpopulation of cells retaining the maximum level of demonstrable activity (minimum degree of stress-associated decline in activity) so far described for ABNC cells. In this way we sought to maximize the opportunities for resuscitation events that might be reflected by recovery of culturable cells from the gut or organs of test animals or by development of clinically apparent infections.

The well-defined S. typhimurium-BALB/c mouse model was used to assess the infective capabilities of nonculturable cells. We found no evidence that nonculturable cells (prepared under conditions tested here) were able to initiate infections by the i.p. or oral routes. This effect was not due to chloramphenicol because antibiotictreated culturable cells (effectively CCN-stressed for $24 \mathrm{~h}$ ) were shown to have equivalent virulence to untreated cells. Even when doses of ABNC cells rigorously defined using the Kogure test, and exceeding the i.p. $\mathrm{LD}_{50}$ by two orders of magnitude, were administered, no evidence of infection was found. We have attempted to define the statistical limitations of our system and can assert that, at a $95 \%$ confidence level, an inoculum of 95000 nonculturable cells, estimated to contain a dose of ABNC cells at least 97-fold above the i.p. $\mathrm{LD}_{50}$ for culturable cells, is not infective.

When our initial studies with MCCN cells did not produce any overt infections we concentrated on attempts to detect culturable salmonella cells in the gastrointestinal tract of orally dosed animals and in the livers and spleens of those that received i.p. inocula. Colonization without overt infection has been reported with previous infectivity studies using apparently nonculturable cells of several enteric pathogens and we were concerned not to miss this (Colwell et al., 1996; Jones et al., 1991). One possible recovery event was observed but 
we were not able to repeat this subsequently with either test strain. Amongst nonculturable inocula administered to over 300 mice, this was the only possible recovery event. We emphasize that such occasional events are to be expected on statistical grounds when large numbers of experiments are done.

We detected no resuscitation events even when nutritionally amended (10\% LB) cell populations containing $\mathrm{ABNC}$ cell doses three orders of magnitude above the oral $\mathrm{LD}_{50}$ were administered (Table 2). Finally in the mixed culturable/nonculturable cell inoculation experiments (Table 3), it could be argued that cell populations that had only recently passed from a culturable to a nonculturable state were given the best possible opportunity to resuscitate with the support of antibioticsensitive culturable cells. Again no resuscitation events were detected.

Although the initiating stress may be defined, the underlying basis for transition between culturable and nonculturable states is not established in most studies concerned with 'VBNC' cells. In particular, several authors have argued that $\mathrm{ABNC}$ cells may represent a long-term survival strategy while others consider such cells to be in a transient or moribund state. Bogosian et al. (2000) have recently shown that the temporarily nonculturable cells of Vibrio vulnificus studied by Oliver and colleagues (Whitesides \& Oliver, 1997) reflect transient peroxide-sensitive populations elicited by temperature downshift. We have been able to detect similar populations (culturable on catalase- or pyruvate-supplemented medium) in the early phase of decline in response to CCN stress but they were always absent by the times at which inocula for animal experiments were prepared (R. J. Smith \& M. R. Barer, unpublished observations). It seems plausible that peroxide-sensitive cells might be recovered by passage through the predominantly anaerobic large intestine. In two recent studies, cells of $S$. typhimurium made nonculturable by UV stress (which also produces oxidative stress) showed no retained infectivity when administered intraperitonelly (Caro et al., 1999; Smith et al., 2000). More recently, Kolling \& Matthews (2001) orally challenged mice with starvationinduced or chlorine-induced nonculturable Escherichia coli O157:H7 cells. No cells were recovered following passage through the gut.

We recognize that alternative stresses provoking nonculturability might give different outcomes. Similar considerations apply to alternative strains of pathogen and host, and to the choice of recovery media and regimens. While noting that these issues cannot be addressed 'by any finite series of experiments' (Bogosian et al., 1998) we conclude that: (1) we have established a rigorous approach to the recognition of in vivo resuscitation events involving defined populations of nonculturable bacterial pathogens; (2) ABNC cells meeting the criteria that others have used to recognize 'viable but nonculturable' bacteria are not infective in our system; (3) the presence of ABNC cells detected by the Kogure method cannot be considered predictive for the infective hazard posed by the material sampled; and (4) at present, there are no validated means other than culture by which molecular signals obtained from clinically relevant samples can be shown to indicate the presence of infective bacteria. We urge others concerned with the issues addressed here to consider adopting comparable approaches to assessing the infectivity of nonculturable bacteria and hope that this will lead to a more precise view of whether and to what extent temporarily nonculturable bacteria (Barer \& Harwood, 1999; Ekweozor et al., 1998) constitute a source and a reservoir for infective diseases.

\section{ACKNOWLEDGEMENTS}

This work was supported by the Biotechnology and Biological Sciences Research Council. We thank Carlos Hormaeche for help in establishing the animal studies, Graeme Proctor for technical assistance, Professor J. N. S. Matthews for assistance with the statistical analyses and Gregg Bogosian and Peter Andrew for commenting on this manuscript.

\section{REFERENCES}

Barcina, I., Arana, I., Santorum, P., Iriberri, J. \& Egea, L. (1995). Direct viable count of Gram-positive and Gram-negative bacteria using ciprofloxacin as inhibitor of cell division. J Microbiol Methods 22, 139-150.

Barer, M. R. (1991). New possibilties for bacterial cytochemistry: light microscopical demonstration of $\beta$-galactosidase in unfixed immobilised bacteria. Histochem J 23, 529-533.

Barer, M. R. \& Harwood, C. R. (1999). Bacterial viability and culturability. Adv Microb Physiol 41, 94-126.

Barer, M. R., Gribbon, L. T., Harwood, C. R. \& Nwoguh, C. E. (1993). The viable but nonculturable hypothesis and medical bacteriology. Rev Med Microbiol 4, 183-191.

Barer, M. R., Kaprelyants, A. S., Weichart, D. H., Harwood, C. R. \& Kell, D. B. (1998). Microbial stress and culturability: conceptual and operational domains. Microbiology 144, 2009-2010.

Bloomfield, S. F., Stewart, G., Dodd, C. E. R., Booth, I. R. \& Power, E. G. M. (1998). The viable but non-culturable phenomenon explained? Microbiology 144, 1-3.

Bogosian, G. (1998). Viable but nonculturable, or dead? ASM News 64, 547.

Bogosian, G., Morris, P. J. L. \& O’Neil, J. P. (1998). A mixed culture recovery method indicates that enteric bacteria do not enter the viable but nonculturable state. Appl Environ Microbiol 64, 1736-1742.

Bogosian, G., Aardema, N. D., Bourneuf, E. V., Morris, P. J. \& O'Neil, J. P. (2000). Recovery of hydrogen peroxide-sensitive culturable cells of Vibrio vulnificus gives the appearance of resuscitation from a viable but nonculturable state. J Bacteriol 182, 5070-5075.

Bovill, R. A. \& Mackey, B. M. (1997). Resuscitation of 'nonculturable' cells from aged cultures of Campylobacter jejuni. Microbiology 143, 1575-1581.

Brayton, P. R., Tamplin, M. L., Huq, A. \& Colwell, R. R. (1987). Enumeration of Vibrio cholerae O1 in Bangladesh waters by fluorescent antibody direct viable count. Appl Environ Microbiol 53, 2862-2865.

Cappelier, J. M., Minet, J., Magras, C., Colwell, R. R. \& Federighi, 
M. (1999a). Recovery in embryonated eggs of viable but nonculturable Campylobacter jejuni cells and maintainance of ability to adhere to HeLa cells after resuscitation. Appl Environ Microbiol 53, 5154-5157.

Cappelier, J. M., Magras, C., Jouve, J. L. \& Federighi, M. (1999b). Recovery of viable but nonculturable Campylobacter jejuni cells in two animal models. Food Microbiol 16, 375-383.

Caro, A., Got, P., Lesne, J., Binard, S. \& Baleux, B. (1999). Viability and virulence of experimentally stressed nonculturable Salmonella typhimurium. Appl Environ Microbiol 65, 3229-3232.

Colwell, R. R. (1996). Global climate and infectious disease: the cholera paradigm. Science 274, 2025-2031.

Colwell, R. R., Brayton, P., Herrington, D., Tall, B., Huq, A. \& Levine, M. M. (1996). Viable but non-culturable Vibrio cholerae O1 revert to a cultivable state in the human intestine. World $J$ Microbiol Biotechnol 12, 28-31.

Department of Health and Social Security (1969). The Bacteriological Examination of Drinking Water Supplies. London: Her Majesty's Stationery Office.

Desmonts, C., Minet, J., Colwell, R. \& Cormier, M. (1990). Fluorescent-antibody method useful for detecting viable but nonculturable Salmonella spp. in chlorinated waste-water. Appl Environ Microbiol 56, 1448-1452.

Ekweozor, C. C., Nwoguh, C. E. \& Barer, M. R. (1998). Transient increases in colony counts observed in declining populations of Campylobacter jejuni held at low temperature. FEMS Microbiol Lett 158, 267-272.

Gaudio, P. A., Sethabutr, O., Echeverria, P. \& Hoge, C. W. (1997). Utility of a polymerase chain reaction diagnostic system in a study of the epidemiology of shigellosis among dysentery patients, family contacts, and well controls living in a shigellosis-endemic area. J Infect Dis 176, 1013-1018.

Gribbon, L. T. \& Barer, M. R. (1995). Oxidative metabolism in nonculturable Helicobacter pylori and Vibrio vulnificus cells studied by substrate-enhanced tetrazolium reduction and digital image processing. Appl Environ Microbiol 61, 3379-3384.

Holmstrom, K., Tolker-Nielsen, T. \& Molin, S. (1999). Physiological states of individual Salmonella typhimurium cells monitored by in situ reverse transcription-PCR. J Bacteriol 181, 1733-1738.

Hormaeche, C. E. (1979). Natural resistance to Salmonella typhimurium in different mouse strains. Immunology 37, 311-318.

Hormaeche, C. E., Kahn, C. M. A., Mastroeni, P., Villarreal, B., Dougan, G., Roberts, M. \& Chatfield, S. N. (1995). Salmonella vaccines: mechanisms of immunity and their use as carriers of recombinant antigens. In Molecular and Clinical Aspects of Bacterial Vaccine Development, pp. 119-154. Edited by D. A. A. Ala'Aldeen \& C. E. Hormaeche. London: Wiley.

Jones, D. M., Sutcliffe, E. M. \& Curry, A. (1991). Recovery of viable but non-culturable Campylobacter jejuni. J Gen Microbiol 137, 2477-2482.

Joux, F., Lebaron, P. \& Troussellier, M. (1997). Succession of cellular states in a Salmonella typhimurium population during starvation in artificial seawater microcosms. FEMS Microbiol Ecol 22, 65-76.

Kaprelyants, A. S. \& Kell, D. B. (1994). Dormancy in stationaryphase cultures of Micrococcus luteus: flow cytometric analysis of starvation and resuscitation. Appl Environ Microbiol 59, 31873196.

Kell, D. B., Kaprelyants, A. S., Weichart, D., Harwood, C. R. \& Barer, M. R. (1998). Viability and activity in readily culturable bacteria: a review and discussion of the practical issues. Antonie Leeuwenhoek 73, 169-187.
Koch, A. L. (1994). Growth measurement. In Methods for General and Molecular Bacteriology, pp. 248-277. Edited by P. Gerhardt, R. G. E. Murray, W. A. Wood \& N. R. Krieg. Washington, DC: American Society for Microbiology.

Kogure, K., Simidu, U. \& Taga, N. (1979). A tentative direct microscopic method for counting live marine bacteria. Can $J$ Microbiol 25, 415-420.

Kolling, G. L. \& Matthews, K. R. (2001). Examination of recovery in vitro and in vivo of nonculturable Escherichia coli O157:H7. Appl Environ Microbiol 67, 3928-3933.

Lisle, J. T., Pyle, B. H. \& McFeters, G. A. (1999). The use of multiple indices of physiological activity to assess viability in chlorine disinfected Escherichia coli O157:H7. Lett Appl Microbiol 29, 42-47.

Maskell, D. J., Hormaeche, C. E., Harrington, K. A., Joysey, H. S. \& Liew, F. Y. (1987a). The initial suppression of bacterial growth in a salmonella infection is mediated by a localized rather than a systemic response. Microb Pathog 2, 295-305.

Maskell, D. J., Sweeney, K. J., O'Callaghan, D., Hormaeche, C. E., Liew, F. Y. \& Dougan, G. (1987b). Salmonella typhimurium aroA mutants as carriers of the Escherichia coli heat-labile enterotoxin B subunit to the murine secretory and systemic immune sytems. Microb Pathog 2, 211-221.

Nilsson, L., Oliver, J. D. \& Kjelleberg, S. (1991). Resuscitation of Vibrio vulnificus from the viable but nonculturable state. J Bacteriol 173, 5054-5059.

Nwoguh, C. E., Harwood, C. R. \& Barer, M. R. (1995). Detection of induced $\beta$-galactosidase activity in individual non-culturable cells of pathogenic bacteria by cytological assay. Mol Microbiol 17, 545-554.

Oliver, J. D. (1999). Viable but nonculturable - alive? ASM News 65, 185-186.

Oliver, J. D. \& Bockian, R. (1995). In vivo resuscitation, and virulence towards mice, of viable but nonculturable cells of Vibrio vulnificus. Appl Environ Microbiol 61, 2620-2623.

Palmer, S. R., Gully, P. R., White, J. M., Pearson, A. D., Suckling, W. G., Jones, D. M., Rawes, J. C. L. \& Penner, J. L. (1983). Waterborne outbreak of campylobacter gastroenteritis. Lancet 1 (8319), 287-290.

Pearson, A. D., Greenwood, M., Healing, T. D., Rollins, D., Shahamat, M., Donaldson, J. \& Colwell, R. R. (1993). Colonization of broiler chickens by waterborne Campylobacter jejuni. Appl Environ Microbiol 59, 987-996.

Popper, K. R. (1972). Conjectures and Refutations: the Growth of Scientific Knowledge, 4th edn. London: Routledge \& Kegan Paul.

Ravel, J., Knight, I. T., Monahan, C. E., Hill, R. T. \& Colwell, R. R. (1995). Temperature-induced recovery of Vibrio cholerae from the viable but nonculturable state-growth or resuscitation. Microbiology 141, 377-383.

Rollins, D. M. \& Colwell, R. R. (1986). Viable but nonculturable stage of Campylobacter jejuni and its role in survival in the natural aquatic environment. Appl Environ Microbiol 52, 531538.

Roszak, D. B. \& Colwell, R. R. (1987). Survival strategies of bacteria in the natural environment. Microbiol Rev 51, 365-379.

Roszak, D. B., Grimes, D. J. \& Colwell, R. R. (1984). Viable but nonrecoverable stage of Salmonella enteritidis in aquatic systems. Can J Microbiol 30, 334-338.

Saha, S. K., Saha, S. \& Sanyal, S. C. (1991). Recovery of injured Campylobacter jejuni cells after animal passage. Appl Environ Microbiol 57, 3388-3389. 
Shahamat, M., Mai, U., Paszkokolva, C., Kessel, M. \& Colwell, R. R. (1993). Use of autoradiography to assess viability of Helicobacter pylori in water. Appl Environ Microbiol 59, 1231-1235.

Sheridan, G. E., Masters, C. I., Shallcross, J. A. \& MacKey, B. M. (1998). Detection of mRNA by reverse transcription-PCR as an indicator of viability in Escherichia coli cells. Appl Environ Microbiol 64, 1313-1318.

Smith, R. J., Kehoe, S., McGuigan, K. G. \& Barer, M. R. (2000). Effects of simulated solar disinfection of water on infectivity of Salmonella typhimurium. Lett Appl Microbiol 31, 284-288.

Stern, N. J., Jones, D. M., Wesley, I. V. \& Rollins, D. M. (1994). Colonization of chicks by noonculturable Camplyobacter spp. Lett Appl Microbiol 18, 333-336.

Votyakova, T. V., Kaprelyants, A. S. \& Kell, D. B. (1994). Influence of viable cells on the resuscitation of dormant cells in Micrococcus luteus cultures held in an extended stationary phase: the population effect. Appl Environ Microbiol 60, 3284-3291.

Whiteley, A. S., O’Donnell, A. G., Macnaughton, S. J. \& Barer, M. R. (1996). Cytochemical colocalization and quantitation of phenotypic and genotypic characteristics in individual bacterial cells. Appl Environ Microbiol 62, 1873-1879.

Whiteley, A. S., Grewal, R., Hunt, A. \& Barer, M. R. (1998). Determining biochemical and physiological phenotypes of bacteria by cytological assay. In Digital Image Analysis of Microbes, pp. 281-308. Edited by M. H. F. Wilkinson \& F. Schut. New York: Wiley.

Whitesides, M. D. \& Oliver, J. D. (1997). Resuscitation of Vibrio vulnificus from the viable but nonculturable state. Appl Environ Microbiol 63, 1002-1005.

Williams, D. A. (1986). Interval estimation of the median lethal dose. Biometrics 42, 641-645.

Xu, H. S., Roberts, N., Singleton, F. L., Attwell, R. W., Grimes, D. J. \& Colwell, R. R. (1982). Survival and viability of nonculturable Escherichia coli and Vibrio cholerae in the estuarine and marine environment. Microb Ecol 8, 313-323.

Received 1 February 2002; revised 13 May 2002; accepted 11 June 2002. 